\title{
Geology of outer Horns Rev, Danish North Sea
}

\author{
Jørn Bo Jensen, Peter Gravesen and Steen Lomholt
}

In 2006, Dong Energy initiated the development of the Horns Rev II offshore wind farm in the North Sea (Fig. 1). In order to evaluate and map the characteristics of the surface features of the sea bed and to characterise the subsurface in the wind farm area, the Geological Survey of Denmark and Greenland (GEUS) conducted a geophysical survey of the area. The survey utilised a variety of instruments: sparker, side-scan sonar, marine caesium magnetometer and a multibeam echo-sounder. In addition, information on the subsurface sediments was obtained by cone penetration tests (CPT) and by drilling to $30-50 \mathrm{~m}$ below the sea bottom. Geological correlation of the CPT results with the other survey results was extremely complicated but was required in order to understand the architecture of the ice marginal glaciotectonic complex. Information on the geology is crucial for evaluation of the geotechnical problems of the region.

\section{Methods}

Shallow seismic, multibeam and coring methods are wellestablished methods in marine geological research. In contrast, marine magnetometer and CPT studies are normally used to find iron objects and for the determination of geotechnical properties. However, both magnetometer and CPT data can yield valuable geological information, as described below.

The magnetometer, which gives information about the ambient magnetic field strength by measuring the variation in caesium electron energy

Fig. 1. Map of the Horns Rev region showing the survey area north of the outer part of Horns Rev. The plan is to build 98 windmills. The survey area covers approximately $58 \mathrm{~km}^{2}$ with a length of $12 \mathrm{~km}$ from south to north and a width of $6 \mathrm{~km}$ from east to west. Modified from Larsen (2003). level, is towed behind the survey vessel. Anomalies in the magnetic field are related to lithological differences in the area. The gridded variations in the strength of the magnetic field, as measured along the survey lines, revealed a spatial pattern. Some areas show homogeneous field strength, whereas other areas show a heterogeneous pattern of field strength. Initially, this pattern appeared to be spatially complex. However, we found that there is a close connection between the magnetic data and large-scale glaciotectonic deformations, as shown by comparisons with other geological and seismic data.

The CPT is carried out using a cylindrical penetrometer with a conical tip (cone) penetrating the ground at a constant rate $\left(2 \mathrm{~cm} \mathrm{~s}^{-1}\right)$. During the penetration, the forces on the cone and the friction sleeve are measured. The CPT results at Horns Rev aid in the foundation design for each of the 98 windmills.

\section{General geology}

Horns Rev can be divided into an inner and outer part separated by a $20 \mathrm{~m}$ deep channel, Slugen (Fig. 1). A reef con-

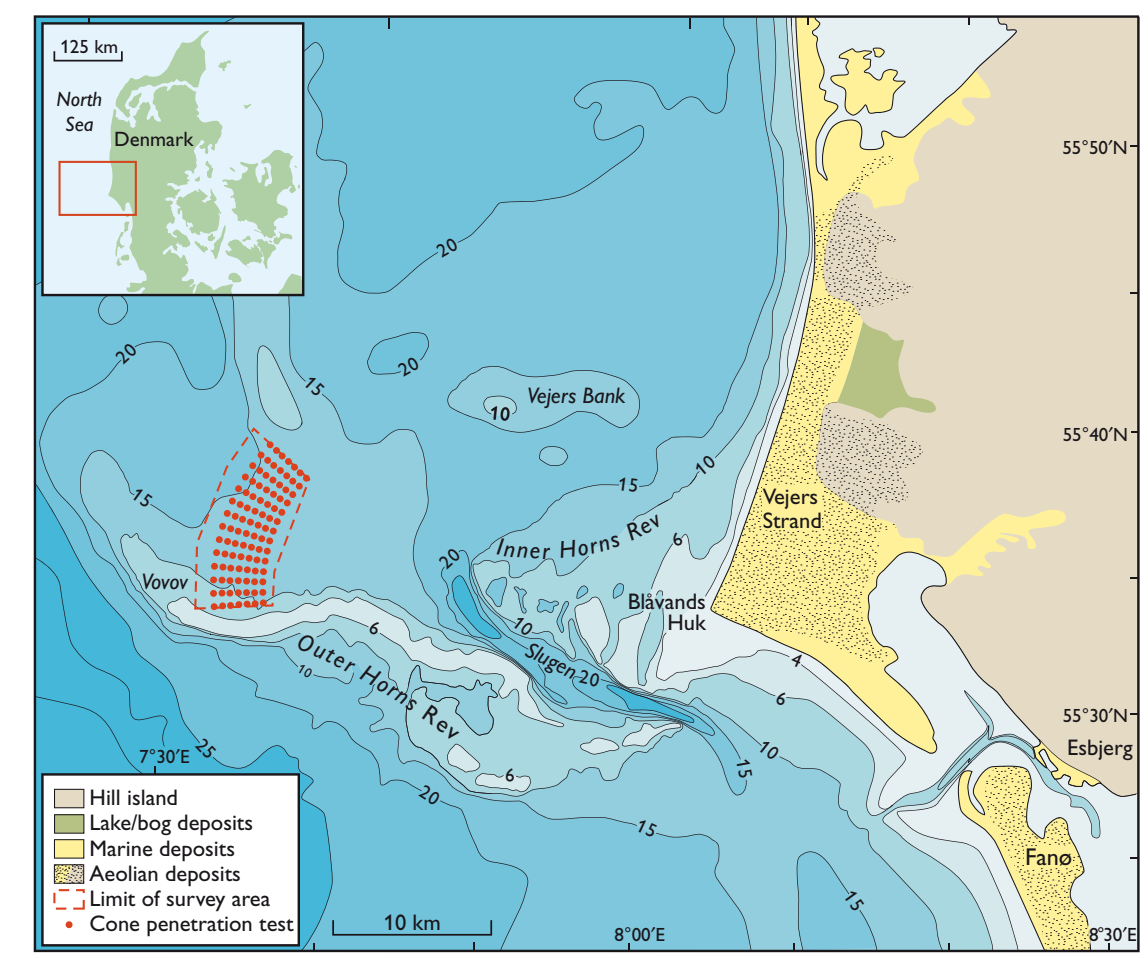


sisting of Holocene shallow submarine sandbanks exists at a water depth of 2-7 $\mathrm{m}$, whereas glacial and interglacial deposits occur in the surrounding area at a water depth of 20-30 m. Tertiary strata, most likely of Miocene age, comprise the basement to the Quaternary deposits located $>50 \mathrm{~m}$ below the sea bed. The wind farm prospect area is located north of the Outer Horns Rev (Fig. 1), at a water depth of 7-18 $\mathrm{m}$ on the Vovov hill island (bakkeø).

Previous investigations have shown that the Horns Rev area was ice-covered during the Elsterian and Saalian glaciations (Larsen \& Andersen 2005). Marine Late Elsterian Holsteinian sediments that were deposited before the Saalian have also been identified in the central North Sea (Long et al. 1988) as well as onshore south-western Jylland (Knudsen 1987, 1994). Eemian marine interglacial sediments have also been recorded in the region (Konradi et al. 2005).

\section{Saalian glacial deposits and other older Quaternary deposits}

The detailed seismic survey results coupled with coring and CPT results (Fig. 2) show that it is possible to identify Elsterian glacial clay and sand till deposits that are overlain by Holsteinian interglacial marine clay, as confirmed by foraminiferal analyses.

The top of the glacial deposits is characterised by a regional erosion surface that appears as a notable seismic unconformity (Figs 2, 3). This reflector represents the surface of the Vovov hill island. Below the unconformity, chaotic seismic reflectors record the existence of small-scale hummocky clinoforms, vertical and sub-horizontal reflectors and

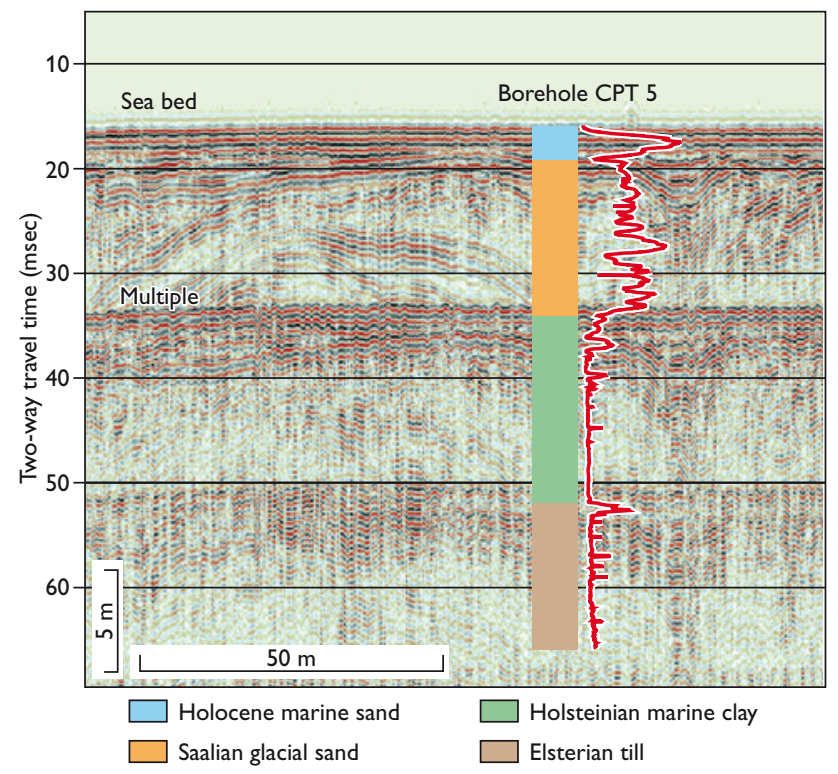

Fig. 2. Seismic example from sparker line 118 showing correlation to borehole and CPT data. channel-like features (Fig. 2). Similar structures that have been recognised in the southern North Sea have been interpreted as representing the ice margin of the Late Saalian Warthe advance (Andersen 2004). On Vovov hill island, the glacial top surface generally lies $18-20 \mathrm{~m}$ below sea level (b.s.l.). However, at the north-eastern rim of the wind farm where the western margin of the Horns Rev valley is situated, the surface drops to $39 \mathrm{~m}$ b.s.l.

The Saalian glacial deposits consist mainly of mediumand coarse-grained sand and gravel with subordinate finegrained sand and silt layers. In addition, fine-grained and silty sand with mica and plant fragments also occurs. This composition is similar to that of the onshore hill islands in western Jylland, where the deposits are also very sandy (Sjørring 1981). Sandy and clayey tills and diamictons with gravels, stones and boulders have also been found.

The chaotic seismic image suggests the presence of glaciotectonically deformed sand and gravel (and tills) that were dislocated at the end of the Saalian glacial stage (Fig. 2). The seismic sections also show several channels and valleys that have incised into the glacial hill (Fig. 3). The reflectors inside these depressions have parallel features that suggest the presence of water-lain sediments. The valleys, therefore, were filled with glaciofluvial sand and gravel, probably during the last phase of the Late Saalian Warthe advance and during decay of the ice. It is important to note, however, that the top sediment deposits in these valleys may also be younger in age.

\section{Eemian deposits}

Earlier studies of foraminiferal faunas from sediment cores suggested that Eemian deposits occur in the Horns Rev area. However, the seismic evidence for Eemian sediments is based on generally indistinct seismic reflectors that are often capped by a sharp top reflector (Konradi et al. 2005).

The Eemian sediments are up to $13 \mathrm{~m}$ thick, with the top of the unit located 11-14 m b.s.l. The deposition of the Eemian unit corresponds to a sea-level high-stand during the Eemian period when the sea covered almost the entire area. The only units not entirely transgressed by the sea were the Saalian glacial deposits at the Vovov hill island.

In the wind farm area, marine Eemian deposits have been identified using biostratigraphical data. The deposits are olive-grey silty clay and sandy silt with sand lenses. The sediments are often bioturbated and contain shells and shell fragments. The marine Eemian layers form a wedge that laps onto the Vovov hill island. Patchy channel infill occurs in the central part of the wind farm area (Fig. 3). Eemian freshwater lake deposits are found below the marine layers. 
Fig. 3. Interpreted sparker line 102 illustrating (a) the seismic stratigraphy and (b) the different types of glaciotectonic deformation classes. For location see Fig. 4.

\section{Holocene deposits}

Due to the absence of Weichselian deposits, Holocene marine deposits directly overlie the Vovov hill island regional erosional surface (Fig. 3), as illustrated in the seismic pattern by internal horizontal layering (Fig. 2). The surface cuts into the Saalian deposits and also into the Eemian marine deposits when present. The Holocene marine deposits form a relatively thin sand cover over all of the glacial and interglacial sediments. In small depressions, early Holocene freshwater sediments with plant remains are occasionally noted. The thickness of the Holocene sand layers ranges from 1 to $2 \mathrm{~m}$ in most parts of the Vovov hill island. In contrast, the thickness of the Holocene deposits increases to 6 to $8 \mathrm{~m}$ in the northern margin of the wind farm area.

\section{Hill island glacial deformations}

Detailed seismic mapping reveals that the wind farm area is located in a complicated ice margin zone of Late Saalian age. The ridges were formed by ice push from the east (Fig. 4). Consequently, the wind farm area is characterised by ice marginal deformations that exhibit correlation with the gridded variations in magnetic field strength along the survey lines (Fig. 4).

Saalian glacio-fluvial sediments were deposited to the west of the glacier margin and are only weakly disturbed by glacial ice push. The deformations associated with the initial ice push mainly affected the central part of the wind farm area (Figs 3 , 4). The western parts of the survey area are characterised by a veneer of Holocene deposits, which are underlain by non-disturbed deposits. On the magnetometer map the western survey areas show no magnetic anomalies due to the simple geology (Fig. 4). The eastern two thirds of the wind farm area are influenced by glacial deformation in the form of thrusting and folding. In the folded areas, the seismic reflectors have a characteristic wavy appearance (Figs 2,3). It is in these areas that Holsteinian, interglacial clay deposits have been found folded into positions close to the sea bed in borehole 5 (Fig. 2). It is believed that soft Miocene clay acted as a décollement layer. On the magnetometer map, the lack of strong magnetic anomalies makes it possible to distinguish folded areas from severely glacially deformed areas (Fig. 4).
Severely disturbed areas interfinger with the folded areas, in a general SW-NE direction (Fig. 4). On the seismic profiles, the reflections are typically chaotic, with the deeper reflectors disappearing completely (Fig. 3). Consequently, the sediment layering would be expected to be chaotic, with many changes in lithology. The magnetometer map shows that anomalies are common in the severely disturbed areas, yielding an uneven map surface that is clearly related to the chaotic lithological distribution (Fig. 4).

Elongated depressions with a NW-SE trend are filled with fluvial deposits (Fig. 4). Examination of these depressions and their fill, as demonstrated in seismic line 102 (Fig. 3), shows that both the fluvial deposits and the channels follow the synclinal depressions of the folded areas. On the magnetometer map (Fig. 4), the fluvial deposits can be identified by relatively large NW-SE-trending anomalies.

\section{Glacial deformation style}

The combination of deformation classes reveals a SW-NEtrending border, separating deformed and undeformed deposits (Figs 3,4). This distribution reveals an ice-push direction from the east and the Holsteinian marine sediments involved suggest that the deformations are associated with the Late Saalian Warthe ice margin, as no younger ice advance reached the area. The Horns Rev ice-margin push moraines can be classified as thin-skinned fold and thrust deformations following Bennett (2001). The large and welldeveloped fold deformation structures indicate that relatively high glacial stress (gravity spreading and/or push) was involved and that Miocene clay layers acted as an important décollement horizon. Outside the ice margin, the rather high foreland strength of the Warthe outwash fan resulted in a marginal zone dominated by thrust deformations. To the west only weakly deformed outwash fan deposits are found. 


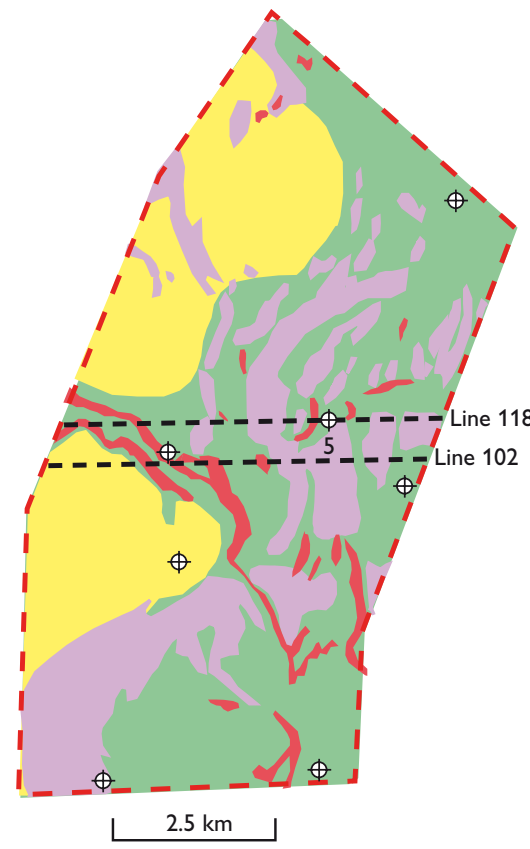

Weakly glacial-disturbed

Glacial-folded

Heavily glacial-disturbed

Fluvial deposits

7 Limit of survey are

\section{Concluding remarks}

Sediment cores and CPT tests from the Horns Rev II wind farm area show that the region is characterised by a complex geology. Large-scale glaciotectonic deformations are related to the Late Saalian Warthe advance with ice push from the east. This investigation also shows that there is a close correlation between magnetometer data and seismically mapped types of deformation structures.

The glacial push moraines developed under conditions of high glacial stress, with Miocene clay acting as décollement horizon. It is important to note that the new evidence from Outer Horns Rev moves the position of the Warthe ice margin more than $50 \mathrm{~km}$ further to the west than formerly suggested.

\section{Acknowledgement}

We thank Dong Energy for the opportunity to present the geological results from the Horns Rev II offshore wind farm project.
Fig. 4. Map distribution of the different types of glaciotectonic deformation structures and magnetometer anomalies. The locations of sparker line 102 and borehole 5 are shown.

\section{References}

Andersen, L.T. 2004: The Fanø Bugt glaciotectonic thrust fault complex, southeastern Danish North Sea. Ph.D. thesis 2004. Danmarks og Grønlands Geologiske Undersøgelse Rapport 2004/30, 143 pp.

Bennett, M.R. 2001: The morphology, structural evolution and significance of push moraines. Earth Science Reviews 53, 197-236.

Knudsen, K.L. 1987: Foraminifera in the Late Elsterian - Holsteinian sequence at Tornskov in south Jutland, Denmark. Danmarks Geologiske Undersøgelse Serie B 10, 7-31.

Knudsen, K.L. 1994: The marine Quaternary in Denmark: a review of new evidence from glacial - interglacial studies. Bulletin of the Geological Society of Denmark 41, 203-218.

Konradi, P.B., Larsen, B. \& Sørensen, Aa.B. 2005: Marine Eemian in the Danish eastern North Sea. Quaternary International 133, 21-31.

Larsen, B. 2003: Blåvands Huk - Horns Rev området - et nyt Skagen? Geologi - Nyt fra GEUS 4, 12 pp. København: Danmarks og Grønlands Geologiske Undersøgelse.

Larsen, B. \& Andersen, L.T. 2005: Late Quaternary stratigraphy and morphogenesis in the Danish eastern North Sea and its relation to onshore geology. Geologie en Mijnbouw 84, 113-128.

Long, D., Laban, C., Streif, H., Cameron, T.D.J. \& Schüttenhelm, R.T.E. 1988: The sedimentary record of climatic variation in the southern North Sea. Philosophical Transactions of the Royal Society of London B318, 523-537.

Sjørring, S. 1981: Pre-Weichselian till stratigraphy in western Jutland, Denmark. Mededelingen Rijks Geologische Dienst 34, 62-68.

\footnotetext{
Authors' address

Geological Survey of Denmark and Greenland, Øster Voldgade 10, DK-1350 Copenhagen K, Denmark. E-mail: jbj@geus.dk
} 